\title{
Seasonal differences in antimalarial activity of hot-water extract of Dichroa febrifuga leaves against Plasmodium yoelii 17XL in ICR mice, with reference to febrifugine and isofebrifugine content
}

\author{
Akira Ishih $^{1 *}$, Kaori Fujii ${ }^{1}$, Mikako Sakai ${ }^{1}$, Masami Iiboshi' ${ }^{2}$, \\ Toshio Miyase ${ }^{2}$, and Mamoru Terada \\ Accepted November, 15, 2002
}

\begin{abstract}
The antimalarial activity of the hot-water extract of leaves and roots of Dichroa febrifuga was evaluated against Plasmodium yoelii 17XL in ICR mice. Untreated control mice died with a gradual body weight loss and increase of parasitemia by day 9 after infection. The hot-water extract of leaves collected in June showed an antimalarial activity, and furthermore the possible adverse side effect was also observed. All mice given orally the extract of leaves $(0.1 \mathrm{~g} / \mathrm{ml})$ collected in June died by day 9 without parasite multiplication. The mice given the lower concentration $(0.025 \mathrm{~g} / \mathrm{ml})$ of the same leaf extract showed low parasitemia levels during administration. Following a transient increase of malaria parasites in the bloodstream, no parasites could be detected by a microscopic examination, and all mice survived during the experiment. On the other hand, the extract of leaves $(0.1 \mathrm{~g} / \mathrm{ml})$ collected in December showed no activity. The extract of roots $(0.1 \mathrm{~g} / \mathrm{ml})$ of $D$. febrifuga collected in December, however, had an antimalarial activity, and three mice out of four survived during the experiment. The leaves collected in June contained about 30 times as much febrifugine and isofebrifugine mixture as those in December.
\end{abstract}

Key words: Plasmodium yoelii 17XL,Dichroa febrifuga, febrifugine, antimalarial activity

\section{INTRODUCTION}

Malaria is one of the most important tropical diseases in the world. World-wide emergence of chloroquineresistant Plasmodium falciparum has stimulated the development of new effective treatments against malaria (Payne, 1987; Winstanley, 2000). Of several strategies on malaria control it is a new interest to investigate the folk medicine exhibiting a potent antimalarial activity. Isolation of artemisinin from leafy portions of Artemisia anпиa L. in 1972 has led to further trial for identifying other medicinal compounds of potential as antimalarial agents from natural products (Iwu et al., 1986; Ajaiyeoba et al., 1999; Isaka et al., 1999; Rahman et al., 1999; Boonlaksiri et al., 2000).

In our continuation of investigation of plants having antimalarial activity, the hot-water extract of leaves of $\mathrm{Hy}$ drangea macrophylla Seringe var. Otaksa Makino showed a high in vivo antimalarial activity against the rodent malaria parasite $P$. yoelii $17 \mathrm{XL}$ though the extract of roots had no activity (Sakai et al., 2000; Ishih et al., 2001). Furthermore the fraction including the febrifugine and isofebrifugine mixture having an antimalarial activity was isolated from the leaves of this plant. These compounds had already been isolated from the roots of Dichroa febrifuga Lour. (Koepfli et al., 1947) and from the leaves of Hydrangea umbellata Rehd. Et Wils. (Ablondi et al., 1952). It is therefore of interest to clarify the distribution and/or content of these principles in the different parts of the plant. This paper deals with a preliminary in vivo antimalarial evaluation of the hot-water extract of leaves of $D$. febrifuga collecting in June or in December using ICR mice infected with $P$. yoelii 17XL.

\section{MATERIALS AND METHODS}

\section{Animals and parasites}

All animal experiments were performed according to the Guidelines for Animal Experimentation, Hamamatsu University School of Medicine. Outbred male ICR mice, 8 weeks old, purchased from SLC Inc. (Hamamatsu, Japan), were used. For experiments, the blood stage parasites of Plasmodium yoelii 17XL from frozen stock were injected into two mice. The mouse showing $10-15 \%$ of parasitemia was bled under ether anaesthesia to collect $P$. yoelii 17XLparasitized blood. Experimental mice were infected intraperitoneally with $1 \times 10^{5}$ parasitized erythrocytes. Infected mice

\footnotetext{
${ }^{1}$ Department of Parasitology, Hamamatsu University School of Medicine, Hamamatsu 431-3192, Japan

2 Department of Pharmacognosy, School of Pharmaceutical Sciences, University of Shizuoka, Shizuoka 422-8526, Japan
} 


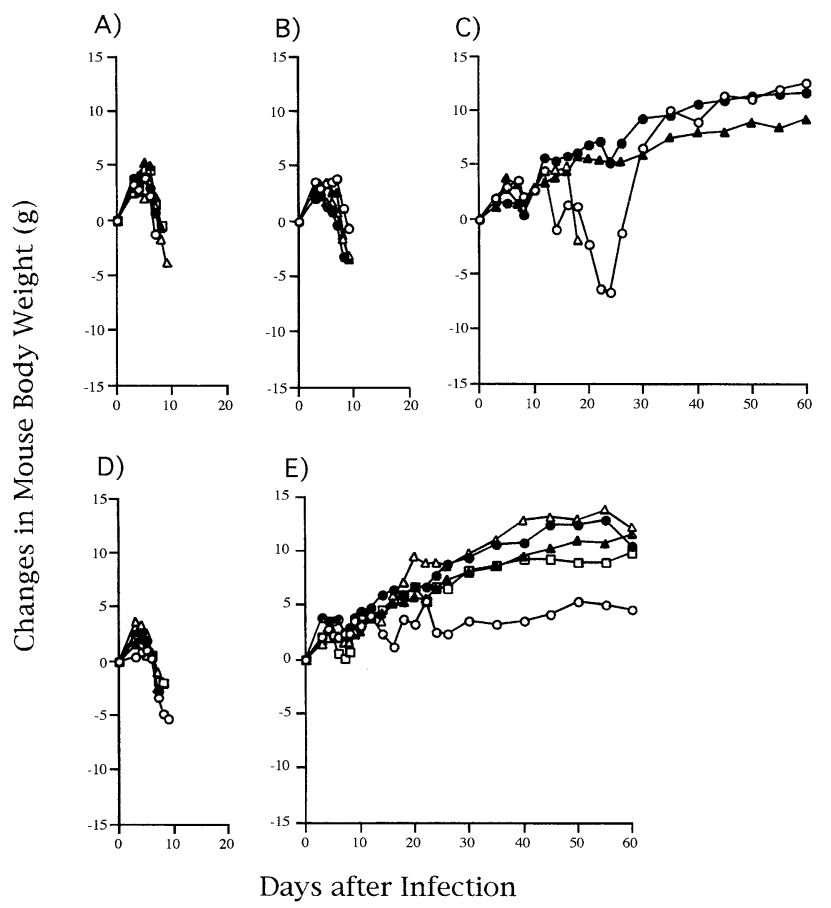

Fig.1. Body weight profile of each mouse in response to treatment with the hot-water extract of roots or leaves of $D$. febrifuga. P. yoelii 17XL-infected mice were orally given each extract at $75 \mu \mathrm{l} / 10 \mathrm{~g}$ body weight, twice a day, for 5 consecutive days from day 3 to day 7 after inoculation intraperitoneally with $10^{5}$ parasitized erythrocytes. Control group ( $\mathrm{A}, \mathrm{n}=5)$ of mice received an equivalent volume of distilled water. Each symbol represents an individual mouse. Extract of leaves collected in December (B, $\mathrm{n}=5 ; 0.1 \mathrm{~g} / \mathrm{ml}$ ), extract of roots collected in December $(\mathrm{C}, \mathrm{n}=4 ; 0.1 \mathrm{~g} / \mathrm{ml})$ and extract of leaves collected in June $(\mathrm{D}, \mathrm{n}=5 ; 0.1 \mathrm{~g} / \mathrm{ml}$ and $\mathrm{E}, \mathrm{n}=5$; $0.025 \mathrm{~g} / \mathrm{ml}$ ).

treated with extracts were monitored for $\%$ parasitemia and days of survival relative to control mice up to 60 days postinfection.

Preparation of the hot-water extract of leaves and roots of D. febrifuga

Leaves (before fallen, dark green and hard) and roots of D. febrifuga were collected from the Botanical Garden, University of Shizuoka in December, 1999, and leaves (in full bloom, green and soft) of the same plant were also collected in June, 2000. Five $g$ of air-dried leaves or roots of the plant put in a herbal bag (Tokiwa Industry, Ehime, Japan) was added with $500 \mathrm{ml}$ of distilled water and boiled. When the fluid volume came to about $250 \mathrm{ml}$, leaves or roots were taken out and the extract was finally concentrated to $50 \mathrm{ml}$. Each hot-water extract (equivalent to the 0.1 $\mathrm{g}$ of dried material $/ \mathrm{ml}$ extract) was stored at $4{ }^{\circ} \mathrm{C}$ until use. Quantitative analysis of febrifugine and isofebrifugine mixture
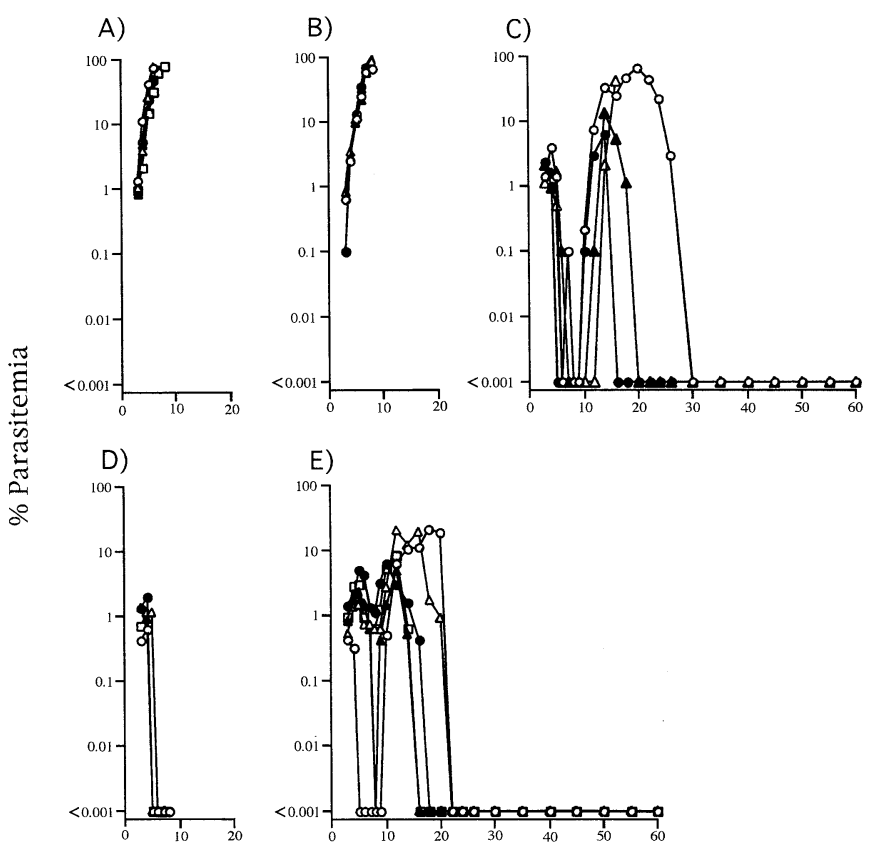

Days after Infection

Fig.2. Parasitemia profile of each mouse in response to treatment with the hot-water extracts of roots or leaves of $D$. febrifuga. P. yoelii 17XL-infected mice were orally given each extract at $75 \mu \mathrm{l} / 10 \mathrm{~g}$ body weight, twice a day, for 5 consecutive days from day 3 to day 7 after inoculation intraperitoneally with $10^{5}$ parasitized erythrocytes. Control group (A, $n=5)$ of mice received an equivalent volume of distilled water. Each symbol represents an individual mouse. Extract of leaves collected in December $(\mathrm{B}, \mathrm{n}=5 ; 0.1 \mathrm{~g} / \mathrm{ml})$, extract of roots collected in December $(\mathrm{C}, \mathrm{n}=4 ; 0.1 \mathrm{~g} / \mathrm{ml})$ and extract of leaves collected in June $(\mathrm{D}, \mathrm{n}=5 ; 0.1 \mathrm{~g} / \mathrm{ml}$ and $\mathrm{E}, \mathrm{n}=5$; $0.025 \mathrm{~g} / \mathrm{ml})$.

Dried leaves or roots ( $1 \mathrm{~g}$ ) of $D$. febrifuga collected in December, 1999 and leaves in June, 2000 were extracted with $50 \mathrm{ml}$ of water under boiling for $1 \mathrm{hr}$ and the extract was filtered and the residue was washed with $20 \mathrm{ml}$ of boiling water. The combined filtrate was acidified with hydrochloric acid $(1 \mathrm{ml})$ and extracted with chloroform $(10 \mathrm{ml})$ three times. To the water layer, $40 \%$ of potassium hydroxide aq. was added until the solution became to alkali. The alkaline solution was extracted with chloroform $(10 \mathrm{ml})$ three times. The chloroform layer was concentrated to dryness after washing with water. The residual chloroform extract was analysed by liquid chromatography (HPLC) comparing the peak area. HPLC condition: Column, Develosil ODS - 74.6 mm x $25 \mathrm{~cm}$ (Nomura Chemical, Aichi, Japan); Solvent, 20 $\mathrm{mM} \mathrm{NaH} \mathrm{PO}_{4}-20 \mathrm{mM} \mathrm{H}_{3} \mathrm{PO}_{4} \quad$ (pH 2.1) / $\mathrm{CH}_{3} \mathrm{CN}$ (9:1); Flow rate $1.0 \mathrm{ml} / \mathrm{min}$; UV, $276 \mathrm{~nm}$; Retention times; 7.4 $\min , 9.2 \mathrm{~min}$.

In vivo antimalarial activity of the hot-water extract of 
leaves collected in June and of leaves or roots collected in December

To evaluate antimalarial activity of hot-water extract, infected ICR mice were divided into four to five per group for activity assay of each extract and untreated control. From3days after injection of parasitized erythrocytes, mice were orally given each hot-water extract at $75 \mu \mathrm{l} / 10 \mathrm{~g}$ body weight in the treated group and distilled water in the control one, respectively, twice a day for5consecutive days.

\section{RESULTS}

Antimalarial activity of the hot-water extract of leaves or roots of $\mathrm{D}$. febrifuga

As shown in Fig.1, mice in the untreated control and groups treated with the extract of leaves $(0.1 \mathrm{~g} / \mathrm{ml})$ collected either in June or in December died from day 7 to day 9 with a gradual body weight loss. However, in the group given the root extract $(0.1 \mathrm{~g} / \mathrm{ml})$, the mouse body weight transiently decreased, but turned to increase in several days, and three mice out of four survived during the experiment. All mice given the extract of leaves $(0.025 \mathrm{~g} / \mathrm{ml})$ collected in June showed a transient body weight loss but survived during the experiment. Malaria parasites appeared from day 3 of infection in the bloodstream of the control and treated groups (Fig.2). Parasitemia of each mouse in the control and the group given the extract of leaves collected in December gradually increased, and all mice died by day 9 . On the other hand, mice in the group given the extract of leaves $(0.1 \mathrm{~g} / \mathrm{ml})$ collected in June showed low parasitemia levels during medication but all mice died by day 9. Autopsy of dead mice showed that the livers became whitish wholly, indicating the hepatotoxicity by higher concentration of the leaf extract. Mice treated with the lower concentration $(0.025 \mathrm{~g} / \mathrm{ml})$ of the extract of leaves collected in June showed low parasitemia levels during medication. After a transient increase of parasitemia, malaria parasites in the bloodstream of mice could not be detected by a microscopic examination from day 16 to day 22 , and all mice survived during the experiment. Mice treated with the root extract also showed low parasitemia levels during medication. On day 10, malaria parasites increased in the bloodstream of the treated mice and one mouse died on day 17 . Then the parasitemia level of three surviving mice decreased and the parasites in the bloodstream could not be detected by a microscopic examination from day 16 to day 30 .

Preparation of alkaloid fraction from leaves and roots

One $g$ of dried leaves of $D$. febrifuga collected in December, 1999 and in June, 2000 afforded 0.024 and 0.718 $\mathrm{mg}$ of febrifugine and isofebrifugine mixture, respectively. One $g$ of dried roots collected in December, 1999 afforded
$0.14 \mathrm{mg}$ of alkaloids.

\section{DISCUSSION}

The roots of $D$. febrifuga have been used as a treatment for malaria in Chinese traditional remedies, and the mixture of febrifugine and isofebrifugine having an antimalarial activity was first isolated from the roots of $D$. febrifuga (Koepfli et al., 1947). In the present study, the hotwater extract of the roots of D. febrifuga collected in December had a direct antimalarial effect on $P$. yoelii 17XL infection in ICR mice; namely, suppression of multiplication of parasites during medication. Besides the extract of the roots, this effect was shown in the hot-water extract of the leaves of $D$. febrifuga collected in June, but not in December. The leaves collected in June contained the febrifugine and isofebrifugine mixture about 5 times as much as the roots collected in December did. Furthermore, the former contained the alkaloid mixture about 30 times as much as the leaves in December did. Kuehl et al. (1948) reported that the total alkaloidal contents having the antimalarial activity were 0.1 to $0.15 \%$ of the dried roots of $D$. febrifuga but the yield of alkaloids from the stem and leaf material was invariably much lower. There is no description available about a season of harvesting leaves, and if the leaves were collected after flowering, the present results coincide with their report. Previously, a solid extract of the leaves of D. febrifuga (Shuu Chi) were found equally effective against $P$. gallinaceum infection in chicks in doses of only about one-fifth of the root extract (Ch'ang Shan) (Jang et al., 1946). Our results also agree with their results. It was also reported that the root samples from India contained only about one-tenth of the alkaloidal fraction present in the Chinese samples. The present results hence suggest that the seasonal changes in activity of hot-water extract of leaves of D. febrifuga might be due to the movement of active compounds from leaves to other parts or the biological and/or chemical inactivity of compounds.

Acute toxicity tests of Ch'ang Shan, the roots of $D$. febrifuga, made on dogs showed a $50 \%$ lethal dose value of $20 \mathrm{~g} / \mathrm{kg}$ (Jang et al., 1946). Fatal dose produced in dogs intense congestion with numerous hemorrhagic patches throughout the whole gastrointestinal tract. Aside from some congestion, no specific lesions were found histologically in the liver, spleen and kidneys. Toxic deaths in mice were observed at $10 \mathrm{mg} / \mathrm{kg}$ for febrifugine (Chien and Cheng, 1970). In the present experiment, the hepatotoxicity of alkaloids is suggested by autopsy of mice given the higher dose of the hot-water extract $(0.1 \mathrm{~g}$ of dried material $/ \mathrm{ml}$ extract) of leaves collected in June. Further experiments are at present being undertaken to examine histologically 
and pharmacologically the toxicity of febrifugine and isofebrifugine mixture in detail.

Recently, the evaluation of antimalarial activity of medicinal plants against malaria was extensively studied, and various active natural plant products were discovered (Iwu et al., 1986; Ajaiyeoba et al., 1999; Rahman et al., 1999; Boonlaksiri et al., 2000). The present study showed that the marked difference in the antimalarial activity of the hotwater extract of $D$. febrifuga leaves collected in between June and December, and thus it should be very important to consider the material conditions such as parts of plants, the geographic conditions, and the season of harvesting, in an ongoing effort to detect the antimalarial activity of medicinal plants and to identify novel antimalarial agents from them.

\section{REFERENCES}

1) Ablondi, F., Gordon, S., Morton, J. II and Williams, J.H. (1952): An antimalarial alkaloid from hydrangea. II. Isolation. J. Org. Chem., 17, 14-18

2) Ajaiyeoba, E.O., Abalogu, U.I., Krebs, H,C. and Oduola, A.M.J. (1999): In vivo antimalarial activities of Quassia amara and Quassia undulata plant extracts in mice. J. Ethnopharmacol., 67, 321-325

3) Boonlaksiri, C., Oonanant, W., Kongsaeree, P., Kittakoop, P., Tanticharoen, M. and Thebtaranonth, Y. (2000): An antimalarial stilbene from Artocarpus integer. Phytochemistry, 54, 415-417

4) Chien, P-L. and Cheng, C.C. (1970): Structural modification of febrifugine. Some methylenedioxy analogs. J. Med. Chem., 13, 867-870

5) Isaka, M., Punya, J., Lertwerawat, Y., Tanticharoen, M. and Thebtaranonth, Y. (1999): Antimalarial activity of macrocyclic trichothecenes isolated from the fungus $M y$ rothecium verrucaria. J. Nat. Prod., 62, 329-331

6) Ishih, A., Ikeya, C., Yanoh, M., Takezoe, H., Miyase, T. and Terada, M. (2001): A potent antimalarial activity of Hydrangea macrophylla var. Otaksa leaf extract against Plasmodium yoelii 17XL in mice. Parasitol. Int., 50, 3339

7) Iwu, M.M., Obidoa, O. and Anazodo, M. (1986): Biochemical mechanism of the antimalarial activity of Azadirachta indica leaf extract. Pharmacol. Res. Commun., 18, $81-91$

8) Jang, C.S., Fu, F.Y., Wang, C.Y., Huang, K.C., Lu, G. and Chou, T.C. (1946): Ch'ang Shan, a Chinese antimalarial herb. Science, 103, 59

9) Koepfli, J.B., Mead, J.F. and Brockman, J.A. Jr. (1947): An alkaloid with high antimalarial activity from Dichroa febrifuga. J. Am. Chem. Soc., 69, 1837

10) Kuehl, F.A.Jr., Spencer, C.F. and Folkers, K. (1948): Alkaloids of Dichroa febrifuga Lour. J. Am. Chem. Soc., 70, 2091-2093

11) Payne, D. (1987): Spread of chloroquine resistance in Plasmodium falciparum. Parasitol. Today, 3, 241-246

12) Rahman, N.N.N.A., Furuta, T., Kojima, S., Takane, K. and Mohd, M.A. (1999): Antimalarial activity of extracts of Malaysian medicinal plants. J. Ethnopharmacol., 64, 249-254

13) Sakai, M., Ishih, A., Takezoe, H., Fujii, K., Sano, M., Asanuma, N., Miyase, T. and Terada, M. (2000): A potent antimalarial activity of hot-water extracts of plants belonging to the family Saxifragaceae against Plasmodium yoelii 17XL in ICR mice [Abstract no A-36]. Jpn. J. Trop. Med. Hyg., 29, 43-44

14) Winstanley, P.A. (2000): Chemotherapy for falciparum malaria: The armoury, the problems and the prospects. Parasitol. Today, 16, 146-153 